\title{
The Effect of Individual Counseling Cognitive Behavioral Therapy for Online Game Addiction on Student SMP Puteri Sion Medan
}

\author{
Rafael Lisinus Ginting ${ }^{1 *}$, Asiah ${ }^{2}$, Suri Handayani ${ }^{3}$, Suryati C Siagian ${ }^{4}$ \\ \{* rafaelginting@gmail.com $\}$ \\ Faculty of Education, Universitas Negeri Medan, Indonesia ${ }^{1}$
}

\begin{abstract}
This study aimed to determine the effect of individual counseling cognitive behavioral therapy against online game addiction on junior high school students of PuteriSion. Subjects in this study were four junior high students the daughter of Zion. The research is a quasi experimentalwithnon equivalent control group design. Data collection techniques used is using the Wilcoxon test to see whether there is the influence of individual cognitive behavioral counseling against online game addiction research on the subject. Wilcoxon's test results at the level of pre-test score obtained in the experimental group was 69 while the post-test scores obtained an average of 124.5 and a pre-test in the control group gained an average score of 73 pre-test and post-test scores on average 77 , means the influence of individual counseling is more significant cognitive behavioral therapy $(124,5>77)$ or $(80.4 \%>5.4 \%)$. This means that the hypothesis is no significant effect of individual counseling service provision cognitive behavioral therapy against online game addiction in private junior high school students received the daughter of Zion.
\end{abstract}

Keywords: Individual counseling, cognitive behavioral therapy, online game addiction.

\section{Introduction}

In Indonesia, the biggest users of online games are teenagers. For teenagers Indonesia online games not uncommon, especially for young people in urban areas. It is alarming, teenagers who are still in school spend time playing online games, causing the decline of their learning achievement. Besides the game around. There are four effects that online gaming addiction on health, personality, education, family and community.

After knowing the impact of online game addiction, researchers feel there should be measures that can help students to reduce addicted to online games, one of them by giving them individual counseling cognitive behavioral therapy. Individual counseling is the process of assistance provided by an expert or a professional to individuals who are having problems in developing their own potential and to find solutions to the problems experienced by counselee together.

This individual counseling using cognitive behavioral therapy approach, which is a counseling approach that focuses on improving cognitive distorted (negative) and then change your thoughts and feelings in a positive direction and is expected to be followed by a change in behavior from negative to positive. So that cognitive behavioral therapy can help the counselee to align your thoughts, feelings and actions. Cognitive behavioral therapy that will 
do the researchers have several techniques that are very helpful in providing counseling to students who are addicted to online games.T he use of cognitive behavioral therapy aimed at reducing the duration of people playing online games. This is according to research by King \&Delfabro 2010 [1] showing that CBT is an effective therapy in overcoming addiction to computer gaming in which there are rules about health, monitor the pattern of the game, change the behavioral habits and oppose thought to play intensive games. It is also in line with research conducted by Young in 2007[1] showing that CBT can be applied to overcome addiction to games in which participants were given CBT is able to solve their own problems.

Wieland [2] provide recommendations to the nurse practitioner psychotherapist that some online gaming addiction treatment, including cognitive behavioral therapy (CBT). Cognitive behavioral therapy (CBT) is a treatment that is based on the idea that the mind determines feelings. With the above reasons, researchers used individual counseling cognitive behavioral therapy to prove the effectiveness of individual counseling cognitive behavioral therapy to reduce addiction to online games on the students.

According to Soetjipto [3] addicted to online games is the increased use of online game play and intense, giving rise to various problems. According to Griffiths [3] online gaming addiction is a chronic disease characterized by the destruction of control on the use of psychoactive materials or clinical behavior. Furthermore, according to Weinsten [2] online gaming addiction is characterized by the extent of excessive gaming gamer that can affect negatively the player of the game. It can be concluded that online gaming addiction is the behavior of someone who can not control themselves in playing online games that can cause behavioral changes in him and have a negative impact on the gamer.

According Lemmens [2] there are seven characteristics of measurement to determine whether or not someone's opium gamers. If there are four characteristics exist in a person, it can be categorized as addicts' game: 1) Salience. Thinking of playing online games all day, without disturbing; 2) Tolerance. Spending time playing online games and do not realize how much time is spent playing games online; 3) Mood modification. Forgetting other activities and do not care about their impact; 4) Relapse. A trend playing online games back after a long absence to play for some reasons; 5) Withdrawal. Feel good or feel something is missing if you do not play online games; 6) Conflict. Fought with others because of excessive play games online, and; 7) Problems.

While the approach of cognitive behavioristik therapy according [4] and Kazdin [5] is as an approach to counseling that is designed to solve the problems of the counselee to perform cognitive restructuring and behavior that deviates by changing the mind, interpretation, conjecture and strategy in response.

Based on the understanding of cognitive behavioral therapy, according to experts, it can be concluded that cognitive behavior therapy is a counseling approach that focuses on improving cognitive distorted (negative) and then change your thoughts and feelings towards the positive and is expected to be followed by changing behavior from negative to positive, so with cognitive behavioral therapy can help the counselee to align your thoughts, feelings and actions (Wilding and Milne, 2013: 16 and Spiegler\&Guevremont, in [1].

Objective cognitive behavior theraphy according Oemarjoed [4] is to invite counselees against wrong thoughts and emotions by presenting evidence contrary to their beliefs about the problems encountered. The counselor should be able to help the counselee to find in nature dogmatic belief in yourself strongly counselees and try to minimize it. According [5] the purpose of cognitive behavioral therapy is to maintain an efficient behavior by strengthening the function of cognitive skills to create change. 
Based on the goal of cognitive behavioral therapy in the above, it can be concluded that the goal of cognitive behavioral therapy is to encourage people to learn to change behavior, calm the mind so that you feel better, think more clearly and can make the right decisions. But in the process of implementing this therapy, counseling, cognitive behavioral therapy should be tailored to the characteristics or counselees problems, of course, the counselor must understand the underlying principles of cognitive behavioral therapy as disclosed by Beck (Munthe, 2014: 15).

The technique used in cognitive behavioral therapy counseling is self-control technique consists of recording yourself, self-evaluation and self-affirmation. Inauguration of a positive self will help counselees transform itself into a more positive picture, and will ultimately increase the confidence and the ability to escape from online gaming addiction by observing the following stages stages.

Table 1. Cognitive Behavior Therapy Process

\begin{tabular}{clc}
\hline No. & Process & Session \\
\hline 1. & Assessment and Diagnosis & 1 \\
2. & $\begin{array}{l}\text { Finding the root cause is sourced from negative emotions, departures thinking } \\
\text { process, and core beliefs that relate to problems counselees }\end{array}$ & 2 \\
3. & $\begin{array}{l}\text { Counselors together counselees intervention plan by providing positive and } \\
\text { negative consequences to the counselee }\end{array}$ & 3 \\
4. & Reorganizing the deviant beliefs & 4 \\
5. & Behavioral interventions & 5 \\
6. & Prevention and self-help training & 6 \\
\hline & & Source: $[6]$
\end{tabular}

\section{Methodology}

This study uses a quantitative approach with quasi experimental research methods that have a control group. Quasi-experimental design used in this study was nonequivalent control group.

Table 2. Research Design

\begin{tabular}{lccc}
\multicolumn{4}{c}{ Table 2. } \\
\hline Group & Pre-test & Treatment & Post-test \\
\hline The experimental group & O1 & X1 & O2 \\
The control group & O3 & - & O4 \\
\hline
\end{tabular}

To obtain accurate data, this research uses collection techniques data using questionnaires and observation sheets to observe the effect of individual counseling to students who are addicted to online games.

Before the questionnaire given to counselees first tested the validity and reliability of measuring instruments, by using data analysis techniques Product Moment [8]. As for the reliability test, formula used in this study is in the alpha formula[8]. Based on calculations using Alpha formula, it is known $\mathrm{r} 11=1.085$ with correlation index in the high category. Anlisis engineering data used is the Wilcoxon test, a test of the parties' rank test "- marked Wilcoxon" proposed by Siegel and Jr. [9] due to the small sample berkuran researchers. 


\section{Result and Discussion}

Based on the results obtained, the average of data lower than the pre-test post-test data in the experimental group, namely $(69<124.5)$, while the control group $(73<77)$. So, there is an average addicted to online games on the students (See Table 3 ).

Table 3. Comparison of Pre-Test and Post-Test Online Game Addiction Changes In Experiments

\begin{tabular}{lccccc}
\hline \multicolumn{5}{c}{ Group } \\
\hline No & Respondents & $\begin{array}{c}\text { Score } \\
\text { Pre-Test }\end{array}$ & $\begin{array}{c}\text { Post-Test } \\
\text { Scores }\end{array}$ & Difference & Percentage \\
\hline 1 & JO & 68 & 115 & 47 & 28.63 \\
$2 \quad$ IR & 70 & 134 & 64 & 33,36 \\
Total Value & 138 & 249 & 111 & \\
Average & 69 & 124.5 & 55.5 & \\
The highest score & 70 & 115 & 45 & \\
lowest Rated & 68 & 134 & 66 & \\
\hline
\end{tabular}

According to the table above is known difference in scores obtained by each student. The following is a description of an increase in change online game addiction:

a. The rate of change JO addicted to online games have the pre-test (before given individual cognitive behavioral counseling services)

b. The rate of change IR addicted to online games have the pre-test (before given individual cognitive behavioral counseling services) amounted to 70 categories of low, thereby changing IR addicted to online games by 64 or $33.36 \%$ in the experimental group.

c. The rate of change PR addicted to online games have the pre-test (before given individual counseling services) by 72 categories of low, thereby changing PR addicted to online games by 6 or $12.01 \%$ in the control group.

d. The rate of change EB addicted to online games have the pre-test (before given individual counseling services) of 74 categories of low, thereby changing PR addicted to online games by 2 or $11.70 \%$ in the control group.

Based on the above it can be seen an increase in online gaming addiction changes before and after treatment in the experimental group and the control group. Before the service given in the experimental group there is an average score of online game addiction behavior change in the experimental group was given 69 and after treatment change interval increase in online gaming addiction behaviors in the experimental group $55.5 \%$ and the average score change behavior online gaming addiction the control group was 73 and after a given treatment interval changes increase online gaming addiction behaviors in the control group $8 \%$,

Hypothesis testing is done by calculating the level marked Wilcoxon test at the Wilcoxon test result the number of levels of calculating the number of levels is positive $=10$ and the number of levels is negative $=0$, so the value of $\mathrm{J}=0$, ie a smaller number of levels.

A table of critical values for the test marked level Wilcoxonfor $n=2, \alpha=0.05$ bidirectional testing $\mathrm{J} 0,05$ (0) H0 is rejected. This means that changes in the behavior of online gaming addiction before and after treatment in the experimental group and the change in the control group is not the same, in this case the students who have been given preferential treatment in the experimental group had a higher score or a significant change from the change in the control group. 
Table 4. Results Comparison of Pre-Test and Post-test Online Game Addiction Changes In Control

\begin{tabular}{lccccc}
\hline No & Respondents & $\begin{array}{c}\text { Score } \\
\text { Pre-Test }\end{array}$ & $\begin{array}{c}\text { Proup } \\
\text { Post-Test } \\
\text { Scores }\end{array}$ & Difference & Percentage \\
\hline 1 & PR & 72 & 78 & 6 & 12.01 \\
2 & 74 & 76 & 2 & 11.70 \\
Total Value & 146 & 154 & 8 & \\
Average & 73 & 77 & 4 & \\
The highest score & 74 & 78 & 4 & \\
lowest Rated & 72 & 76 & 4 & \\
\hline
\end{tabular}

Testing the hypothesis above, further reinforced by the equation calculation formula, the number of levels terkecillah used, while equation is used for foundation testing value $\mathrm{Z}$.

$\mathrm{H} 0$ is rejected if $\mathrm{z}$ count $<\mathrm{z}$ table. Since the $\mathrm{z}$ score -1.35 and the count is smaller than the $\mathrm{Z}$ value table is -1.96 , value -1.96 obtained from the value $\mathrm{Z} \alpha / 2$ value of table $Z 0,05 / 2=$ $\mathrm{Z} 0,025=-1.96$. Thus, $\mathrm{H} 0$ is rejected, which means the effect of treatment in the experimental group is more significant than the change in treatment in the control group, which means individual counseling cognitive behavioral therapy is more efficient and gives effect to the online gaming addiction in students.

\section{Conclusion}

Based on the results of this study concluded that the implementation of individual counseling cognitive behavioral therapy in the experimental group had a more significant effect on the online gaming addiction in class VIII SMP PuteriSion Medan. Results of the calculations in the experimental group obtained Jhitung $=4$. With $\alpha=0.05$ and $n=4$, then based on the list, Jtabel $=0$. From these data it appears that $\mathrm{J}$ count $>$ Jtabel $=(4>0)$, before being given treatment or pre-test in the experimental group gained an average score of 69 online gaming addiction and post-test scores obtained an average of 124.5 addicted to online games and test pre-test in the control group gained an average of 73 online gaming addiction behavior and post-test gained an average of 77 online gaming addiction behavior. Then the behavior of students addicted to online games after being given the treatment in the experimental group was higher than the changes experienced by the control group after treatment $(124.5>77)$ or $80.4 \%>5.4 \%$. Hipotsis then $\mathrm{H} 0$ is rejected, this is reinforced by the equation of formula $\mathrm{Z}$. Because $\mathrm{Z}$ count value is -1.35 and it was smaller than the $\mathrm{z}$ value table is -1.96 .

\section{References}

[1] E. Y. Siregar, "Penerapan Cognitive Behavior Therapy (CBT) Terhadap Pengurangan Durasi Bermain Games Pada Individu Yang Mengalami Games Addiction," J. Psikol., vol. 9, no. 1, pp. 17-24, 2013.

[2] W. Sanditaria, "Adiksi Bermain Game Online pada Anak Usia Sekolah di Warung Internet Penyedia Game Online Jatinangor Sumedang," Students e-Journal, vol. 1, no. 1, p. 32, 2012.

[3] W. Fauziawati, "Upaya Mereduksi Kebiasaan Bermain Game Online Melalui Teknik Diskusi Kelompok," PSIKOPEDAGOGIA J. Bimbing. dan Konseling, vol. 4, no. 2, pp. 115-123, 2015.

[4] I. Muqodas, "Cognitive-Behaviour Theraphy: Solusi Pendekatan Praktek Konseling di Indonesia.” Makalah, 2011. 
[5] T. Safaria, Terapi kognitif perilaku untuk anak. Penerbit Graha Ilmu, 2004.

[6] A. K. Oemarjoedi, "Pendekatan cognitive behavior dalam psikoterapi," Jakarta Kreat. Media, 2003.

[7] S. Arikunto, Prosedur Penelitian Suatu Pendekatan Praktik. Jakarta: Rineka Cipta, 2016.

[8] S. Arikunto, Prosedur penelitian: Suatu pendekatan praktik. Rineka Cipta, 1992.

[9] S. Nana, "Penilaian Hasil Proses Belajar Mengajar, Cetakan ketujuh, Bandung, PT," Remaja Rosdakarya, 2001. 